\title{
Differential regulation of neurotrophin expression in human bronchial smooth muscle cells Cecilia Kemi ${ }^{1}$, Johan Grunewald ${ }^{1}$, Anders Eklund ${ }^{1}$ and Caroline Olgart Höglund*1,2
}

\author{
Address: ${ }^{1}$ Department of Medicine, Division of Respiratory Medicine, Lung Research Laboratory, Karolinska Institutet and Karolinska University \\ Hospital Solna, 17176 Stockholm, Sweden and 2Department of Physiology and Pharmacology, Karolinska Institutet, 17177 Stockholm, Sweden \\ Email: Cecilia Kemi - Cecilia.Kemi@ki.se; Johan Grunewald - Johan.Grunewald@ki.se; Anders Eklund - Anders.Eklund@karolinska.se; \\ Caroline Olgart Höglund* - Caroline.Olgart@ki.se \\ * Corresponding author
}

Published: 29 January 2006

Respiratory Research 2006, 7:18 doi:10.1186/1465-9921-7-18

This article is available from: http://respiratory-research.com/content/7/I//8

(C) 2006 Kemi et al; licensee BioMed Central Ltd.

This is an Open Access article distributed under the terms of the Creative Commons Attribution License (http://creativecommons.org/licenses/by/2.0), which permits unrestricted use, distribution, and reproduction in any medium, provided the original work is properly cited.
Received: 22 September 2005

Accepted: 29 January 2006

\begin{abstract}
Background: Human bronchial smooth muscle cells (HBSMC) may regulate airway inflammation by secreting cytokines, chemokines and growth factors. The neurotrophins, including nerve growth factor (NGF), brain-derived neurotrophic factor (BDNF) and neurotrophin-3 (NT-3), have been shown to be elevated during airway inflammation and evoke airway hyperresponsiveness. We studied if HBSMC may be a source of NGF, BDNF and NT-3, and if so, how inflammatory cytokines may influence their production.
\end{abstract}

Methods: Basal and cytokine (IL-I $\beta$, IFN- $\gamma$, IL-4)-stimulated neurotrophin expression in HBSMC cultured in vitro was quantified. The mRNA expression was quantified by real-time RT-PCR and the protein secretion into the cell culture medium by ELISA.

Results: We observed a constitutive NGF, BDNF and NT-3 expression. IL-I $\beta$ stimulated a transient increase of NGF, while the increase of BDNF had a later onset and was more sustained. COX-inhibitors (indomethacin and NS-398) markedly decreased IL-I $\beta$-stimulated secretion of BDNF, but not IL-I $\beta$-stimulated NGF secretion. IFN- $\gamma$ increased NGF expression, down-regulated BDNF expression and synergistically enhanced IL-I $\beta$-stimulated NGF expression. In contrast, IL-4 had no effect on basal NGF and BDNF expression, but decreased IL-I $\beta$-stimulated NGF expression. NT-3 was not altered by the tested cytokines.

Conclusion: Taken together, our data indicate that, in addition to the contractile capacity, HBSMC can express NGF, BDNF and NT-3. The expression of these neurotrophins may be differently regulated by inflammatory cytokines, suggesting a dynamic interplay that might have a potential role in airway inflammation.

\section{Background}

Allergic asthma is characterised by an inflammatory airway obstruction induced by specific allergen [1]. In addition, structural cells of the allergic airways are often hyperresponsive to non-specific stimuli, which synergises with the inflammatory response to aggravate disease [2]. While the pathogenesis of allergen-induced inflammatory airway obstruction is relatively well understood [1], we 
know much less about the regulation of airway hyperresponsiveness. According to current models, it involves proliferation and phenotypic changes of structural cells (e.g. smooth muscle cells, fibroblasts) and nerve cells in the airways, which contribute to enhanced airway resistance $[2,3]$.

Neurotrophins, such as nerve growth factor (NGF), brainderived neurotrophic factor (BDNF) and neurotrophin-3 (NT-3) were initially discovered as factors that regulate development, differentiation and survival of neurones (for review see [4]). However, neurotrophins have recently been implicated also in inflammatory responses. For example, NGF enhances survival, activation and mediator release from multiple cell types of the immune system, such as mast cells, lymphocytes and eosinophils (for review see $[5,6])$. In agreement with a pathogenic role in allergic asthma, elevated levels of NGF, BDNF and NT-3 have been detected in blood and locally in the airways in patients with asthma [7-10], a response that can be further augmented after allergen challenge $[9,11]$. In animal models, NGF and BDNF may contribute to the development of bronchial hyperresponsivness (BHR) [12-14]. A direct action on neurones may be one part of this response since NGF increases the number of neurones and the neuropeptide content in the airways $[15,16]$. However, NGF has also been suggested to participate in tissue remodelling processes and fibrosis in the airways $[17,18]$, suggesting important roles for neurotrophins in many pathogenic processes that characterise pulmonary inflammation and allergic disease.

Different members of the neurotrophin family often show distinct functional effects, a phenomenon that has been mostly studied in the nervous system [19-21], but has also been observed in epithelial cells [22]. NGF and BDNF may also play distinct roles in airway inflammation. For example, antibody blockage of NGF affected early inflammatory responses in murine asthma while neutralisation of BDNF reduced only chronic airway obstruction and BHR but not inflammation $[23,24]$. In addition, BDNF has been shown to enhance pollen-specific IgE production while NGF and NT-3 were without effect [25]. It is unknown whether similar functional differences between the neurotrophins are operating in human airway inflammation.

The source and regulation of neurotrophin expression in the airways is not fully understood. A local NGF production by structural cells, including airway smooth muscle cells, epithelial cells, fibroblasts and infiltrating inflammatory cells has been suggested in vivo and in vitro $[10,11,26-28]$. Compared to NGF, less is known about the cellular sources of BDNF and NT-3 in human airways, but the presence of BDNF and NT-3 in human bronchial smooth muscle (HBSMC) and epithelium has been implied using immunohistochemistry on bronchial biopsies from non-asthmatic subjects [28]. In the present study, we used primary HBSMC to study the expression patterns of three members of the neurotrophin family, NGF, BDNF and NT-3, after stimulation with inflammatory cytokines.

Our data show that HBSMC constitutively expressed all neurotrophins analysed. NGF and BDNF, but not NT-3, were induced by IL-1 $\beta$, but with markedly different kinetics. While NGF was induced more rapidly and peaked at 6 hours after the start of stimulation, BDNF was maximally induced only after 24 hours. A recent study has identified a critical role for cyclooxygenase (COX) for BDNF production [29]. This led us to explore the possibility that an intermediary mediator, such as a COX-2-derived mediator, would be involved in the IL-1 $\beta$-dependent BDNF secretion. Interestingly, the induction of BDNF was shown to involve a COX-2-dependent pathway. Furthermore, the addition of Th 1 and Th 2 cytokines affected synthesis of NGF but affected BDNF marginally. Our data suggest that HBSMC display a differential and complex transcriptional regulation of three different members of the neurotrophin family, which may provide a framework for differential functional effects of neurotrophins in airway inflammation and asthma, controlled by HBSMC and regulated by inflammatory cytokines.

\section{Methods}

Culture of human bronchial smooth muscle cells (HBSMC) HBSMC in primary culture from a healthy donor (Promocell, Heidelberg, Germany) were grown in monolayer in DMEM (Sigma-Aldrich, St Louis, MO, USA) supplemented with 10\% FBS (Invitrogen, Rockville, MD, USA), $100 \mathrm{U} / \mathrm{mL}$ penicillin, $100 \mu \mathrm{g} / \mathrm{mL}$ streptomycin, $2 \mu \mathrm{g} / \mathrm{mL}$ amphotericin B (Fungizone $e^{\circledast}$, all Sigma-Aldrich) and 0.12 $\mathrm{IU} / \mathrm{mL}$ insulin (Lilly, St Cloud, France) in $25 \mathrm{~cm}^{2}$ flasks (Becton Dickinson Falcon, Franklin Lakes, NJ, USA). Cells at passage 9 were used in all experiments. Cells were positive for smooth muscle specific $\alpha$-actin and in light microscopy the cells displayed the reported characteristics of viable smooth muscle cells in culture [30].

\section{Experimental procedure}

At $80 \%$ confluence cells (corresponding to 800000 cells/ $25 \mathrm{~cm}^{2}$ flask) were growth arrested for $24 \mathrm{~h}$ in a low-FBS $(0.3 \%)$ insulin-free DMEM. Time-dependent pattern of neurotrophin expression was studied with and without cytokines, IL-1 $\beta 10 \mathrm{U} / \mathrm{mL}$ (Boehringer Ingelheim, Mannheim, Germany), IL-4 and IFN- $\gamma 10 \mathrm{ng} / \mathrm{mL}$ (both R\&D Systems, Oxon, United Kingdom), for 0.5, 1, 2.5, 6, 24 and $48 \mathrm{~h}$ in fresh low-FBS medium. Dose-dependent effects of IL-1 $\beta$, IL- 4 and IFN- $\gamma$ were studied by stimulating cells in fresh low-FBS medium for 6, 24 and $48 \mathrm{~h}$ with or 
Table I: PCR primers and TaqMan probes

\begin{tabular}{|c|c|c|}
\hline \multirow[t]{4}{*}{ NGF } & Forward & 5': ACA TTA ACA ACA GTG TAT TCA AAC AGT ACT TT \\
\hline & Reverse & 5': CGG CAC CCG CTG TCA \\
\hline & Probe & 5': ACC AAG TGC CGG GAC CCA AAT CC \\
\hline & Length of product (bp) & 79 \\
\hline \multirow[t]{4}{*}{ BDNF } & Forward & 5': AGT GCC GAA CTA CCC AGT CGT A \\
\hline & Reverse & 5': TAT GAA TCG CCA GCC AAT TCT \\
\hline & Probe & 5': TGC GGG CCC TTA CCA TGG ATA GC \\
\hline & Length of product (bp) & 74 \\
\hline \multirow[t]{4}{*}{ NT-3 } & Forward & 5': GAT AAA CAC TGG AAC TCT CAG TGC AA \\
\hline & Reverse & 5': GCC AGC CCA CGA GTT TAT TGT \\
\hline & Probe & 5': CAA ACC TAC GTC CGA GCA CTG ACT TCA GA \\
\hline & Length of product (bp) & 84 \\
\hline
\end{tabular}

without increasing cytokine concentrations; IL-1 $\beta$ 0.1-30 $\mathrm{U} / \mathrm{mL}, \mathrm{IL}-4$ and IFN- $\gamma$ 0.1-30 ng/mL. The effects of COXinhibition on IL-1 $\beta$-dependent neurotrophin secretion were studied by using the unselective COX-inhibitor indomethacin $(10 \mu \mathrm{M})$ and the COX-2 inhibitor NS-398 $(10 \mu \mathrm{M})$. The chosen dose of indomethacin and NS-398 has been shown to effectively inhibit IL-1 $\beta$-stimulated COX activity [31]. The inhibitors were added $1 \mathrm{~h}$ prior to the addition of IL-1 $\beta(10 \mathrm{U} / \mathrm{mL})$, and NGF and BDNF were measured in the cell culture supernatants following $48 \mathrm{~h}$ of IL- $1 \beta$ stimulation.

In preliminary studies IL-1 $\beta$ gave a maximal increase in NGF mRNA-expression at $6 \mathrm{~h}$, whereas IFN- $\gamma$ gave a significant increase at $48 \mathrm{~h}$. Therefore, to evaluate effects of IFN$\gamma$ on IL-1 $\beta$-stimulated NGF mRNA-expression, HBSMC were treated with IFN- $\gamma(0.1-30 \mathrm{ng} / \mathrm{mL})$ for $42 \mathrm{~h}$, where after IL-1 $\beta(10 \mathrm{U} / \mathrm{mL})$ was added and the stimulation continued for an additional $6 \mathrm{~h}$. The effects of IFN- $\gamma$ on IL-1 $\beta$ stimulated BDNF and NT-3 mRNA expression were studied at both 6 and 48 h of stimulation with a combination of IL-1 $\beta(10 \mathrm{U} / \mathrm{ml})$ and IFN- $\gamma(0.1-30 \mathrm{ng} / \mathrm{ml})$. The effects of IL-4 $(0.1-30 \mathrm{ng} / \mathrm{mL})$ on IL-1 $\beta(10 \mathrm{U} / \mathrm{mL})$-stimulated NGF mRNA-expression were studied following $6 \mathrm{~h}$ of combined stimulation. The effects of IL-4 $(0.1-30 \mathrm{ng} / \mathrm{mL})$ on IL-1 $\beta(10 \mathrm{U} / \mathrm{mL})$-stimulated BDNF and NT-3 mRNAexpression were studied following both 6 and $48 \mathrm{~h}$ of combined stimulation.

After stimulation cell supernatants were collected, centrifuged $\left(+4^{\circ} \mathrm{C}, 400 \times \mathrm{g}, 10 \mathrm{~min}\right)$ and stored at $-70^{\circ} \mathrm{C}$ until analysis. Cells were collected in $1 \mathrm{~mL}$ RLT lysis buffer (Qiagen Inc, Valencia, CA, USA) and kept at $-70^{\circ} \mathrm{C}$ until analysis.

\section{Extraction of total RNA and cDNA synthesis}

Total RNA was extracted from the RLT lysis buffer using the RNeasy extraction kit and genomic DNA was removed by DNAse I (all products from Qiagen Inc), according to the manufacturer's protocol. RNA was reverse transcribed in a $20 \mu \mathrm{l}$ final volume using $10 \mu \mathrm{l}$ of total RNA, $20 \mathrm{mM}$ random primers, $200 \mu \mathrm{M}$ of each deoxyribonucleoside triphosphate (dNTP), 40 units RNAsin (all products from Pharmacia Biotech, Uppsala, Sweden) and 200 units SUPERSCRIPT ${ }^{\mathrm{TM}}$ II RNase $\mathrm{H}^{-}$Reverse Transcriptase (Invitrogen), according to the protocol and with the buffers supplied by the manufacturer. To enable detection of eventual genomic DNA contamination, non-reversed transcribed total RNA was diluted 1:1 with water whereafter it was analysed the same way as cDNA.

\section{Quantification of neurotrophin cDNA by real-time PCR}

The basal and IL-1 $\beta$-, IL-4- and IFN- $\gamma$-stimulated NGF, BDNF and NT-3 mRNA expression was quantified following $0.5,1,2.5,6,24$ and 48 h of cell culture using the ABI Prism 7700 Sequence Detection System (Applied Biosystems, Foster City, CA, USA) utilising the 5' nuclease method (TaqMan) with a two-step polymerase chain reaction (PCR) protocol $\left(95^{\circ} \mathrm{C}\right.$ for $10 \mathrm{~min}$, followed by 40 cycles of $95^{\circ} \mathrm{C}$ for $15 \mathrm{sec}$ and $60^{\circ} \mathrm{C}$ for $\left.1 \mathrm{~min}\right)$. The PCR reaction was set up in a volume of $25 \mu \mathrm{l}$, with $2 \mu \mathrm{l}$ cDNA diluted $1 / 5$ and a final concentration of $1 \times$ Buffer A, $5 \mathrm{mM}$ $\mathrm{MgCl}_{2}, 0.05 \mathrm{U} / \mu \mathrm{l}$ AmpliTaq Gold (all from Applied Biosystems), $200 \mathrm{nM}$ dNTP-mix (Pharmacia Biotech), 300 $\mathrm{nM}$ of each primer and $200 \mathrm{nM}$ probe. All primers and probes were purchased from Applied Biosystems, including primers and probe for the housekeeping gene $18 \mathrm{~S}$ rRNA, which sequences were commercially available. The neurotrophin primer and probe sequences were designed using the PRIMER EXPRESS Software (Applied Biosystems) according to the manufacturer's guidelines and the target primers and probes were for technical reasons placed within a single exon. None-reversed transcribed RNA was analysed in the same way as cDNA as a negative control. Primer and probe sequences are shown in Table 1. The probes were synthesised with the fluorescent reporter dye FAM (6-carboxy-fluorescein) attached to the 5 '-end and a quencher dye TAMRA (6-carboxy-tetrame- 
A

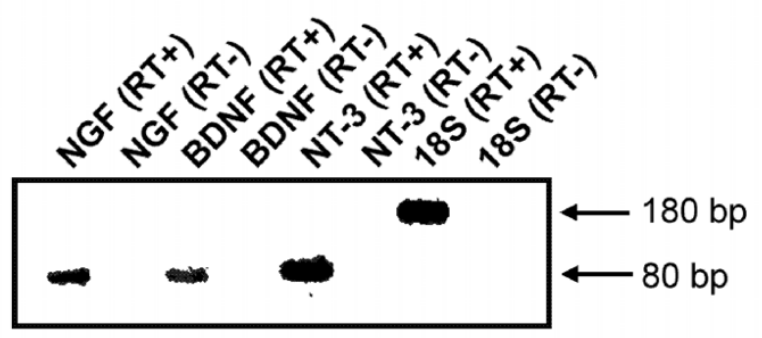

B

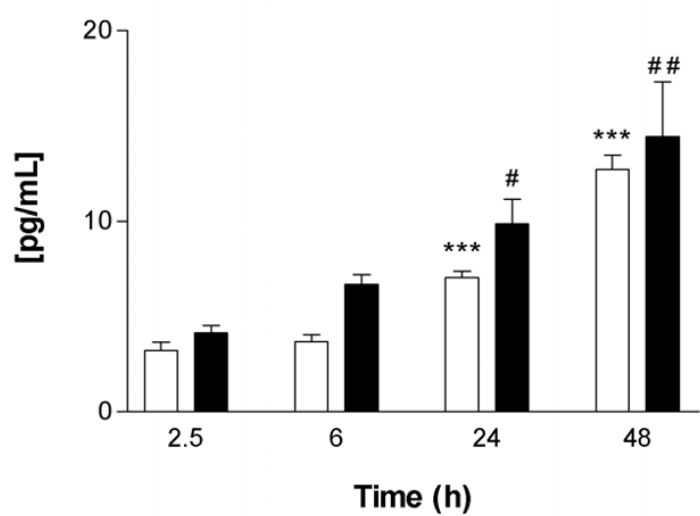

Figure I

Constitutive expression of neurotrophins by non-treated HBSMC evaluated by RT-PCR and ELISA. (A) Expression of NGF, BDNF, NT-3 mRNA and I8S rRNA. Reversed transcribed (RT+) and non-reversed transcribed (RT-) mRNA or rRNA are displayed. (B) NGF (white bars) and BDNF (black bars) protein secretion determined by ELISA. Data presented as mean \pm SEM of 3-4 independent experiments performed in duplicate. In (B) ***: $p<0.00$ I for NGF, and \#: $p<0.05$ and \#\#: $<0.0$ I for BDNF, versus $2.5 \mathrm{~h}$

thyl-rhodamine) to the 3'-end. Relative quantification of the cDNA levels were performed using the 'Relative Standard Curve method', described in detail in User Bullentin \#2 (Perklin Elmer Applied Biosystems, 1997), with amplification of neurotrophins and the housekeeping gene $18 \mathrm{~S}$ in separate tubes. Briefly, standard curves for each neurotrophin and $18 \mathrm{~S}$ were created using five serial dilutions $(1: 1,1: 2,1: 10,1: 20$ and 1:100) of cDNA from the human foetal fibroblast cell line HFL-1 (American Type Culture Collection, Rockville, MD, USA). By plotting the values for the threshold cycle $\left(C_{T}=\right.$ the first cycle in which the amount of amplicon exceeds the threshold) against the different dilutions a standard curve was obtained. All samples were run in duplicates and the mean values were used in further analysis. The relative amount of neurotrophin mRNA in each sample was then calculated as the ratio between the neurotrophin mRNA and the housekeeping gene $18 \mathrm{~S}$ rRNA before samples were compared.

\section{Detection of neurotrophin expression by conventional PCR}

Constitutive mRNA expression of neurotrophins by HBSMC was analysed following 0.5, 1, 2.5, 6, 24 and 48 $\mathrm{h}$ of cell culture by conventional PCR on a GeneAmp PCR System 9600 (Applied Biosystems). PCR was performed in a total volume of $20 \mu \mathrm{l}$ using $2 \mu \mathrm{l}$ of $1 / 5$ diluted cDNA and a final concentration of $200 \mathrm{nM}$ dNTP-mix (Pharmacia Biotech), $300 \mathrm{nM}$ of each primer (Tabel 1), $1 \times$ TaqGold-buffer II, $1.9 \mathrm{mM} \mathrm{MgCl}_{2}$ and $0.05 \mathrm{U} / \mu \mathrm{l}$ AmpliTaq
Gold (all Applied Biosystems). The thermal cycling conditions were: $94^{\circ} \mathrm{C}$ for $12 \mathrm{~min}$, followed by 30 cycles for $18 \mathrm{~S}$ and 40 cycles for the neurotrophins of $94^{\circ} \mathrm{C}$ for $30 \mathrm{sec}$, $60^{\circ} \mathrm{C}$ for $30 \mathrm{sec}$ and $72^{\circ} \mathrm{C}$ for $1 \mathrm{~min}$, before ending with $72^{\circ} \mathrm{C}$ for $9 \mathrm{~min}$. The products were analysed on a $1.5 \%$ agarose (Invitrogen) gel complemented with $0.025 \%$ ethidium bromide (Pharmacia Biotech), where a $1 \mathrm{~kb}$ DNA-ladder (Invitrogen) was run in parallel to the samples. The gels were pictured using a Kodak Digital Science $1 \mathrm{D}^{\mathrm{TM}}$ analysing system (Kodak Scientific Imaging Systems, New Haven, CT, USA).

\section{Quantification of neurotrophin protein by enzyme-linked immunosorbent assay (ELISA)}

To quantify the NGF, BDNF and NT-3 protein levels in cell culture supernatants, commercially available ELISA kits were used, according to the manufacturer's instructions (Promega, Madison, WI, USA). All measurements were performed in duplicate. Constitutive protein secretion was analysed following 2.5, 6, 24, and $48 \mathrm{~h}$ of cell culture for NGF and BDNF, and 2.5, 6, 24, 48 and 72 h of cell culture for NT-3. IL-1 $\beta$ stimulated protein expression was analysed at 2.5, 6, 24 and $48 \mathrm{~h}$ for all three neurotrophins. Protein expression following IL- $1 \beta$ stimulation and COXinhibition was analysed following $48 \mathrm{~h}$ of stimulation. Prior to analysis of NT-3 the supernatant was concentrated using the Amicon Ultra-15 Centrifugal Filter Units (Millipore, Carrigtwohill, Ireland), with a molecular weight cut off of 5,000 $\mathrm{Da}$, according to the protocol 
A

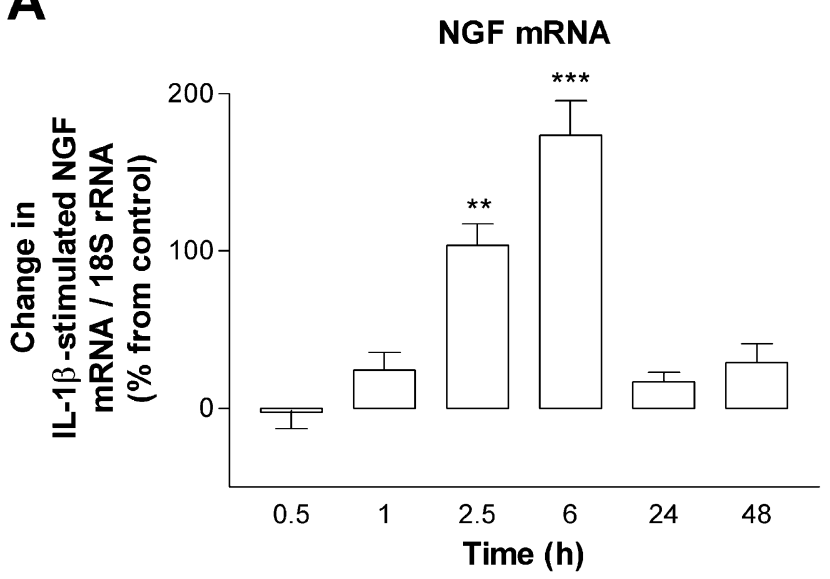

C

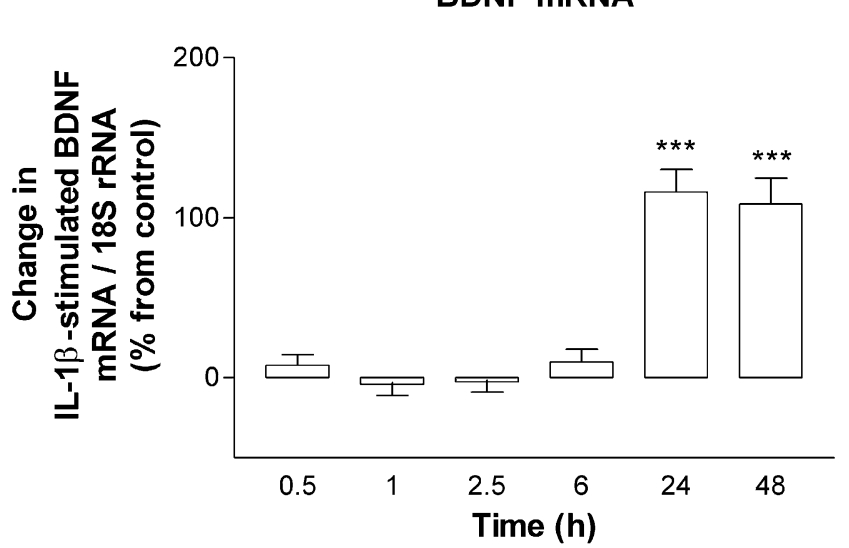

B NGF protein

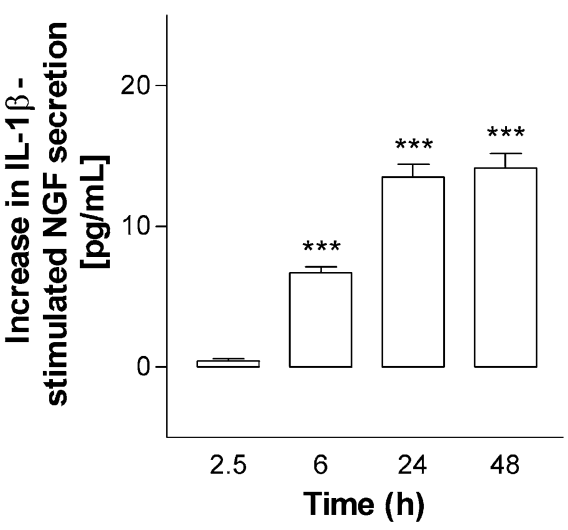

D

BDNF protein

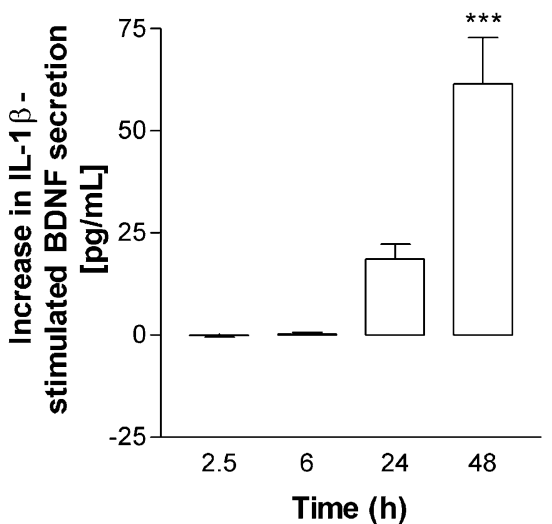

Figure 2

Time-course effects of IL-I $\beta(10 \mathrm{U} / \mathrm{mL})$ on NGF and BDNF mRNA and protein expression in HBSMC evaluated with real-time RT-PCR and ELISA, respectively. (A) NGF mRNA; (B) NGF protein; (C) BDNF mRNA and (D) BDNF protein. The IL-I $\beta$ dependent effects on neurotrophin mRNA expression and secreted protein are expressed as change in neurotrophin mRNA (\%) and protein release $(\mathrm{pg} / \mathrm{mL})$ from baseline level of time-related control. Unstimulated control is set to $0(\%$ or $\mathrm{pg} / \mathrm{mL}$, respectively). Data are presented as mean \pm SEM of 4-10 independent experiments performed in duplicate. In (A) and (C): **: $p<0.01$ versus $0.5 h, * * *: p<0.001$ versus $0.5 h . \ln (B)$ and $(D): * * *: p<0.00 I$ versus $2.5 h$.

obtained from the manufacturer. The detection range for NGF and BDNF was $2.0-250 \mathrm{pg} / \mathrm{mL}$, and for NT-3 2.4$150 \mathrm{pg} / \mathrm{mL}$.

\section{Statistical analysis}

NGF, BDNF and NT-3 mRNA expression was formulated as the ratio of neurotrophin cDNA to $18 \mathrm{~S}$ rRNA and expressed as neurotrophin cDNA/18S rRNA. Effects of cytokines on neurotrophins mRNA expression and pro- tein secretion were expressed as change in mRNA (\%) and protein release $(\mathrm{pg} / \mathrm{mL})$ from baseline level of timerelated control. Results are presented as mean \pm SEM of 310 independent experiments performed in duplicate. Raw data were compared using one-way analysis of variance (ANOVA) followed by Tukey's post test. Differences were considered significant at $\mathrm{p} \leq 0.05$. All analyses were performed using GraphPad InStat 3.01 (Graph Pad Software, San Diego, CA, USA). 


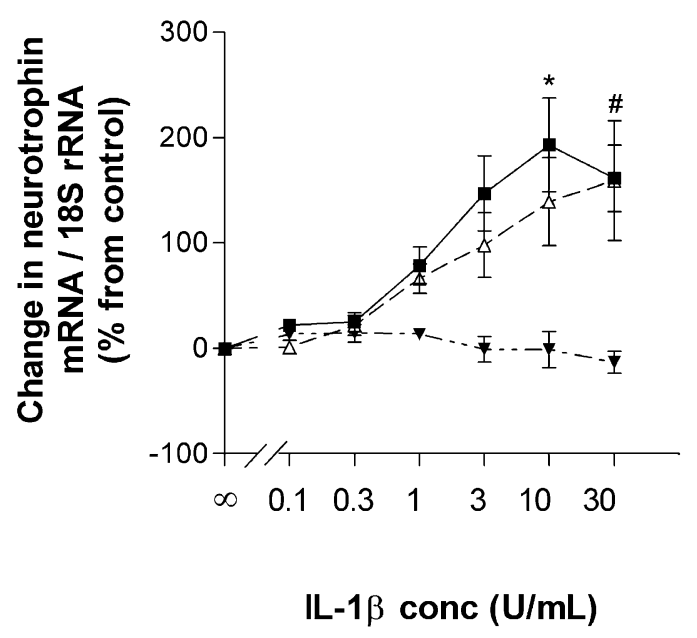

Figure 3

Dose-dependent effects of IL-I $\beta$ on neurotrophin mRNA expression in HBSMC evaluated by real-time RT-PCR. NGF mRNA expression evaluated at $6 \mathrm{~h}$ (solid squares); BDNF mRNA expression evaluated at $48 \mathrm{~h}$ (open triangle); NT-3 mRNA evaluated at $48 \mathrm{~h}$ (closed triangles). The IL-I $\beta$ dependent effects on neurotrophin mRNA expression are expressed as change in neurotrophin mRNA (\%) from baseline level of time-related control. Unstimulated control is set to $0 \%$. Data are expressed as mean \pm SEM of 3 independent experiments performed in duplicate. *: $p<0.05$ for NGF and $\#: p<0.05$ for BDNF versus unstimulated control.

\section{Results}

Neurotrophin mRNA and protein expression in HBSMC In order to study the expression of NGF, BDNF and NT-3 by unstimulated cultured HBSMC, we analysed cellular mRNA as well as secreted protein in the culture supernatants, at six different time points $(0.5,1,2.5,6,24$ and 48 h) after the start of the cultures. HBSMC constitutively expressed all three neurotrophins at the mRNA level. In Figure $1 \mathrm{~A}$ a representative expression is pictured following $2.5 \mathrm{~h}$ of incubation. Furthermore, NGF and BDNF proteins accumulated in the culture supernatants over time. Hence, NGF and BDNF reached detectable levels following $2.5 \mathrm{~h}$ of cell culture and increased further over the next $48 \mathrm{~h}$ (Figure 1B). In contrast to NGF and BDNF, NT-3 protein was made in very low amounts, reaching detectable levels $(3.1 \pm 0.7 \mathrm{pg} / \mathrm{mL}$ ) only after $72 \mathrm{~h}$ of culture (not shown).

\section{Effects of IL-I $\beta$ on neurotrophin mRNA and protein expression}

We next investigated the ability of the proinflammatory cytokine IL-1 $\beta$ to induce neurotrophin expression in
HBSMC. At $2.5 \mathrm{~h}$ after addition of IL-1 $\beta(10 \mathrm{U} / \mathrm{mL})$, NGF mRNA expression was significantly increased compared to control cultures. A maximal increase was reached after $6 \mathrm{~h}$ of stimulation, after which mRNA levels dropped to near basal levels (Figure 2A). A corresponding increase in NGF protein secretion was detected, reaching a maximal increase after $24-48 \mathrm{~h}$ of IL-1 $\beta$ stimulation (Figure $2 \mathrm{~B}$ ). Interestingly, the induction of BDNF mRNA expression by IL-1 $\beta(10 \mathrm{U} / \mathrm{mL})$ showed a completely different kinetics. At $6 \mathrm{~h}$, no increase was seen and only at $24 \mathrm{~h}$ after stimulation (which was our next observation point) we observed a significant upregulation of BDNF mRNA (Figure $2 \mathrm{C}$ ). A corresponding elevation of BDNF protein secretion was evident at $24 \mathrm{~h}$, a secretion that was further enhanced at $48 \mathrm{~h}$ (Figure 2D). The increases in NGF and BDNF mRNA expression by IL-1 $\beta$ - were both dosedependent (0.1-30 U/mL) (Figure 3). NT-3 mRNA expression was unaltered at any tested dose of IL- $1 \beta$ as evaluated at 2.5, 6, $24 \mathrm{~h}$ (not shown) and $48 \mathrm{~h}$ (Figure 3).

\section{Effects of COX-inhibitors on IL-I $\beta$-stimulated NGF and BDNF protein secretion}

We hypothesised that the slower induction kinetics of BDNF compared to NGF after IL-1 $\beta$ stimulation reflected an involvement of COX in the induction of BDNF but not of NGF. To test this, we evaluated the effects of the COXinhibitors indomethacin and NS-398 (both $10 \mu \mathrm{M}$ ) on the secretion of these two neurotrophins. BDNF secretion after IL-1 $\beta(10 \mathrm{U} / \mathrm{mL})$ stimulation was significantly inhibited by both indomethacin and NS-398 (Figure 4). None of the COX inhibitors altered basal NGF or BDNF secretion (not shown) and they were inefficient in preventing IL-1 $\beta$-stimulated NGF secretion (Figure 4). These data suggest that the production of BDNF, but not of NGF, in HBSMC involves COX-2 and the synthesis of prostaglandins.

\section{Effects of IFN- $\gamma$ and IL-4 on neurotrophin mRNA expression}

Allergic asthma is characterised by a disturbed balance between Th 1 and Th2 cytokines towards Th2 dominance [1]. To test the hypothesis that Th 1 and Th 2 cytokines displayed different effects on neurotrophin gene expression by HBSMC, we treated HBSMC with either IFN- $\gamma$ or IL-4 and measured the relative mRNA content of NGF and BDNF at various time points after addition of the cytokine. IFN- $\gamma$ enhanced NGF mRNA expression in a time- (Figure 5A) and dose (0.1-30 ng/mL, not shown)dependent manner, displaying a maximally enhanced NGF mRNA level at $48 \mathrm{~h}$ after the start of stimulation (Figure $5 \mathrm{~A}$ ). In contrast to NGF, BDNF mRNA expression was not induced. If anything, we observed a small decrease in relative BDNF mRNA content during the first $6 \mathrm{~h}$ of IFN- $\gamma$ stimulation, after which it returned to baseline levels at 48 $\mathrm{h}$ after the start of the culture (Figure 5B). NT-3 expression 
A

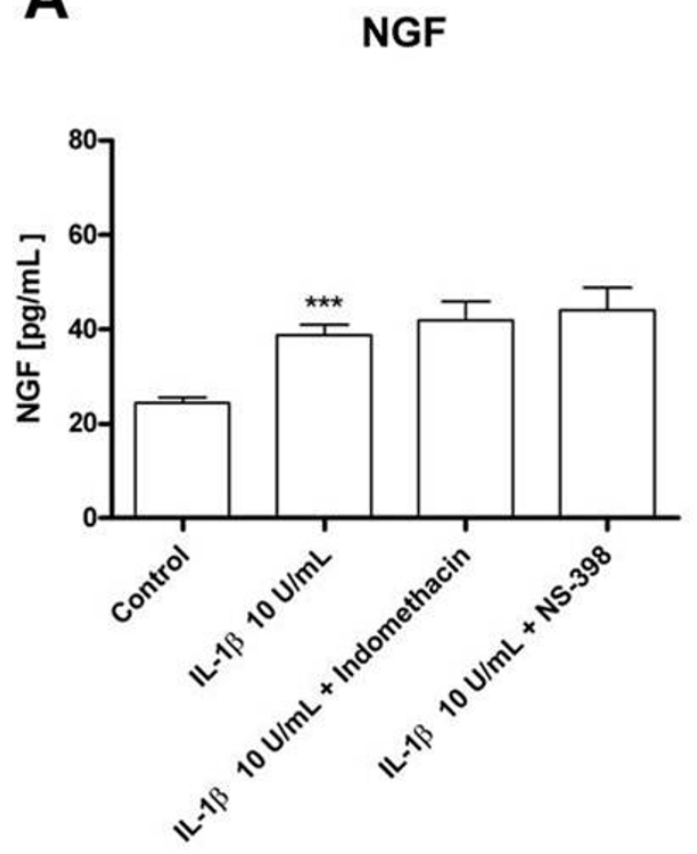

B

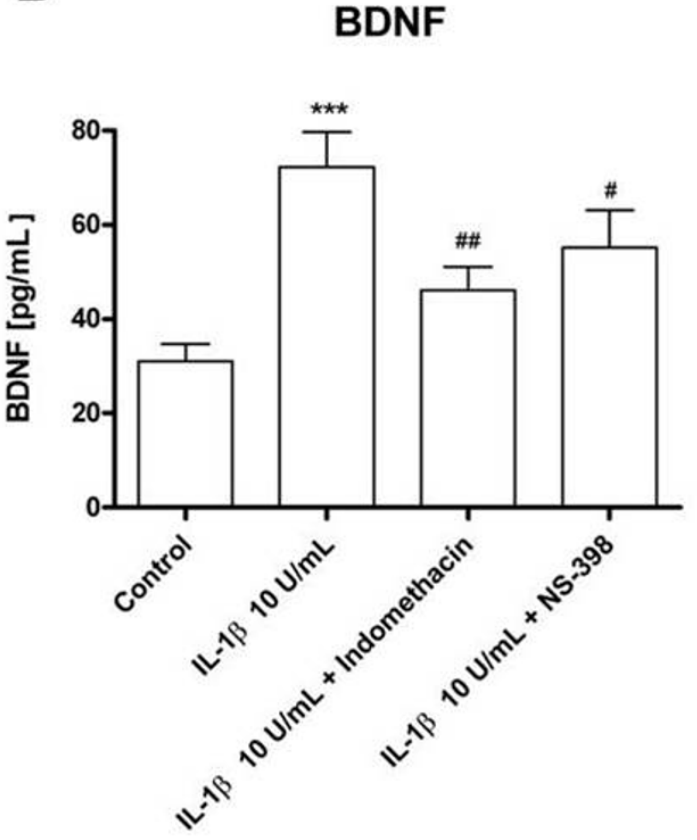

\section{Figure 4}

Effects of the COX-inhibitors indomethacin and NS-398 (both $10 \mu \mathrm{M})$ on IL-I $\beta(10 \mathrm{U} / \mathrm{mL})$-stimulated NGF (A) and BDNF (B) secretion by HBSMC, evaluated by ELISA. Data are presented as mean \pm SEM of 6 independent experiments. ***: $p<0.00$ I versus control, and \#: $\mathrm{p}<0.05$, \#: $\mathrm{p}<0.0 \mathrm{I}$ versus IL-I $\beta(10 \mathrm{U} / \mathrm{mL})$ alone.

was unaltered in response to IFN- $\gamma$ under the tested conditions (not shown). In contrast to IFN- $\gamma$, IL-4 (0.1-30 U/ $\mathrm{mL}$ ) did not have any affect on basal NGF, BDNF or NT-3 expression at any of the tested intervals $(0.5,1,2.5,6,24$, $48 \mathrm{~h}$ ) (not shown).

\section{Effects of different combinations of IL-I $\beta$, IFN- $\gamma$, IL-4 on neurotrophin mRNA expression}

During an inflammatory response in vivo, $\mathrm{T}$ cell-derived cytokines such as IFN- $\gamma$ and IL- 4 are likely to act in concert with proinflammatory cytokines, such as IL-1 $\beta$. An interesting question was therefore whether IFN- $\gamma$ or IL- 4 would work in synergy with IL-1 $\beta$. Since the kinetics of NGF induction in HBSMC was different between IFN- $\gamma$ (peak at $48 \mathrm{~h}$ ) and IL-1 $\beta$ (peak at $6 \mathrm{~h}$ ) we cultured HBSMC with IFN- $\gamma$ for $42 \mathrm{~h}$ and added IL-1 $\beta$ during the last $6 \mathrm{~h}$ of culture to maximise the effect of each cytokine. Under such culture conditions, we observed a potent and dosedependent synergistic behaviour on NGF secretion by IFN- $\gamma(0.1-30 \mathrm{ng} / \mathrm{mL})$ and IL-1 $\beta(10 \mathrm{U} / \mathrm{mL})$ (Figure 6A). We also tested IL-4 (0.1-30 ng/mL) in this protocol. To our surprise, we noted that IL-4 reduced the stimulatory effects of IL-1 $\beta(10 \mathrm{U} / \mathrm{mL})$ on NGF mRNA expression, reaching a maximal reduction with an IL-4 dose of $10 \mathrm{ng} /$ $\mathrm{mL}$ as evaluated at $6 \mathrm{~h}$ of combined stimulation (Figure
6B), despite the fact that IL-4 did not affect NGF secretion by itself.

In contrast, the IL-1 $\beta$ (10 U/mL)-stimulated expression of BDNF mRNA was not altered by IFN- $\gamma$ or IL- 4 at any tested dose $(0.1-30 \mathrm{ng} / \mathrm{mL}$ ) or time ( 6 and $48 \mathrm{~h}$, data not shown). In addition, NT-3 mRNA expression was not altered by combining IL- $1 \beta(10 \mathrm{U} / \mathrm{mL})$ with either INF- $\gamma$ or IL- 4 at any tested dose $(0.1-30 \mathrm{ng} / \mathrm{mL}$ ) or time ( 6 and $48 \mathrm{~h}$, data not shown).

\section{Discussion}

IL-1 $\beta$ is a pro-inflammatory cytokine of known importance in asthma pathogenesis [32]. The effect of IL-1 $\beta$ on NGF expression by structural cells in the airways, including HBSMC, has already been studied in some detail [27]. However, our study is the first to use HBSMC to systematically investigate how IL-1 $\beta$-induced expression of NGF relates to IL-1 $\beta$-induced expression of BDNF and NT-3, two other members of the neurotrophin family. This is an important question to address since these three neurotrophins have been shown to display different functional activities, including in asthmatic disease [19-22,24,25]. We found several differences in the regulation of these three neurotrophins. First, mRNA synthesis of NGF and 
A

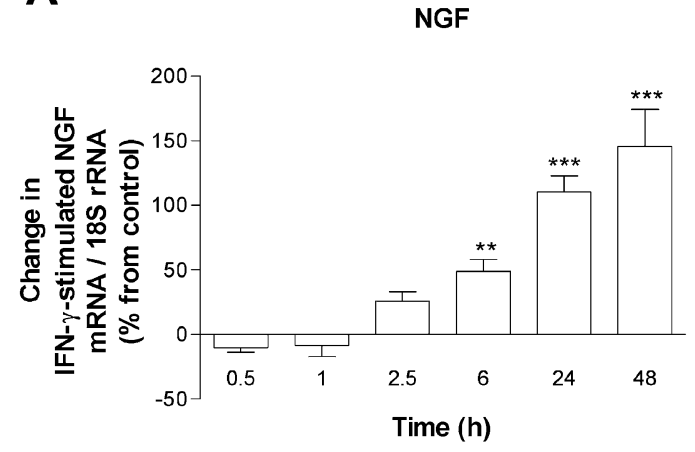

B

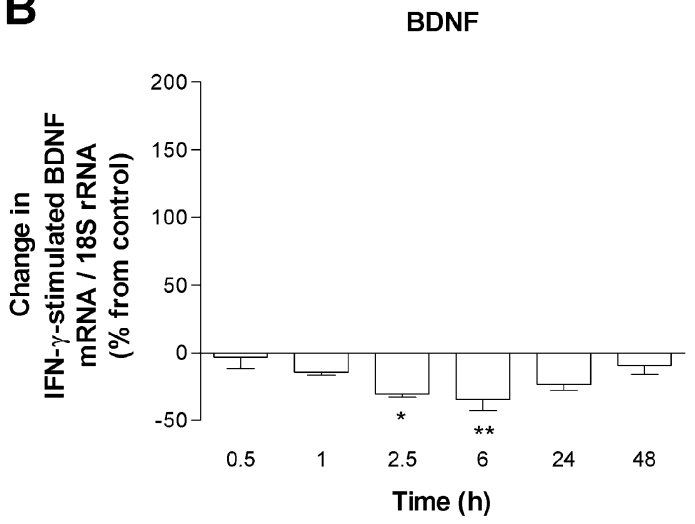

\section{Figure 5}

Time-course effects of IFN- $\gamma(10 \mathrm{ng} / \mathrm{mL})$ on NGF (A) and BDNF (B) mRNA expression in HBSMC evaluated by real-time RTPCR. The IFN- $\gamma$-dependent effects on neurotrophin mRNA expression are expressed as change in neurotrophin mRNA (\%) from baseline level of time-related control. Unstimulated control for each time-point is set to $0 \%$. Data are presented as mean \pm SEM of 6 independent experiments performed in duplicate. *: $\mathrm{p}<0.05,{ }^{*}: \mathrm{p}<0.0 \mathrm{I}, *^{* *}: \mathrm{p}>0.00 \mathrm{I}$ versus $0.5 \mathrm{~h}$.

BDNF, but not of NT-3, was stimulated in a dose-dependent fashion by IL-1 $\beta$. Since nonstimulated HBSMC expressed mRNA from NT-3, the lack of induction of NT3 cannot be explained by lack of basal gene transcription. Rather, differences in critical IL-1 $\beta$ response elements in the NT-3 gene may be crucial. Alternatively, NT-3 expression may require a different set of intermediate factors compared to NGF and BDNF that may be lacking in our HBSMC. It is interesting to note that NT-3 expression, but not NGF or BDNF expression, is transcriptionally downregulated in chronic obstructive pulmonary disease, suggesting that cells from the airways may be poor at producing NT-3 compared to other neurotrophins [33].

A second difference we observed was that the two neurotrophins that were induced by IL-1 $\beta$ (NGF and BDNF) showed markedly different kinetics of induction. While NGF mRNA induction was transient and high already at 6 $\mathrm{h}$ after addition of IL-1 $\beta$, BDNF showed a more sustained expression pattern with a slower onset and a maximal induction after $24 \mathrm{~h}$. With regard to the kinetics of NGF induction, our data is in line with that of Freund and coworkers, who similarly demonstrated a rapid and transient increase of NGF by IL- $1 \beta$ in airway smooth muscle cells, although Freund and co-workers reported a maximal upregulation at $2.5 \mathrm{~h}$ of IL-1 $\beta$ stimulation [27]. It may be speculated that the difference in time-course effects by IL$1 \beta$ on NGF expression is dependent on the origin of the smooth muscle cells. Hence, the question of whether cells from different locations in the bronchial tree have different synthetic properties needs further investigation. In both our, and in the study by Freund and co-workers, NGF protein induction was detected with a significant delay. The dramatic differences in mRNA and protein induction between NGF and BDNF shown in our study demonstrate remarkable heterogeneity in the regulation of neurotrophin expression in HBSMC. One possible explanation for this difference could be the involvement of additional intermediary mediators in BDNF induction. Our finding that secretion of BDNF, but not NGF, was inhibited by the unselective COX inhibitor indomethacin and the COX-2 inhibitor NS-398 imply the prostaglandins as such intermediary mediators. A regulatory role of COX-2 in BDNF secretion adds to recent data showing that prostaglandins can stimulate the expression of BDNF in mouse astrocytes [34] and that COX inhibitors are able to counteract BDNF-mediated effects of spatial learning in a mouse in vivo model [29]. Interestingly, Toyomoto and co-workers found that also NGF expression was stimulated by prostaglandins [34]. More work is needed to investigate whether our observation of a differential role of COX inhibitors on NGF and BDNF secretion in HBSMC will also be observed in vivo.

We also found that the lymphocyte-derived cytokines IFN- $\gamma$ and IL-4 affected neurotrophin expression differently. For example, the Th1 cytokine IFN- $\gamma$ induced NGF expression but not BDNF expression, and IFN- $\gamma$ synergised with IL-1 $\beta$ to enhance NGF gene transcription, implying an important role for IFN- $\gamma$ in the airway inflammation. In addition, we found IL-4, a typical Th2 cytokine, to downregulate IL-1 $\beta$ stimulated NGF expression. In relation to the asthma, these results are surprising, but may reflect a more complex involvement of Th1/Th2 

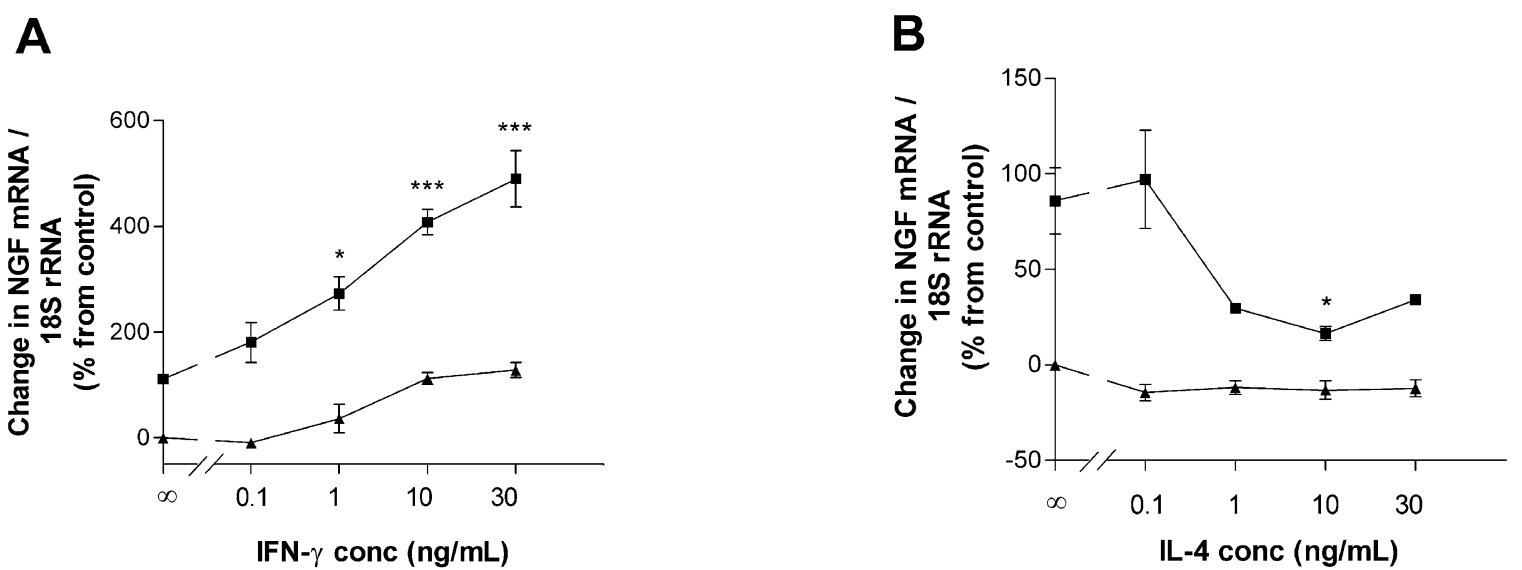

Figure 6

Dose-dependent effects of IFN- $\gamma$ and IL-4 on IL-I $\beta(10 \mathrm{U} / \mathrm{mL})$-stimulated NGF expression in HBSMC evaluated by real-time RT-PCR. Solid triangles illustrate effects of IFN- $\gamma(A)$ and IL-4 (B) alone and solid squares illustrate IL-I $\beta$ in combination with IFN- $\gamma(A)$ and IL-4 (B). The IFN- $\gamma$ - or IL-4-dependent effects on IL-I $\beta$-stimulated NGF mRNA expression are expressed as change in NGF mRNA (\%) from baseline level of time-related control. Unstimulated control is set to $0 \%$. Data are presented as mean \pm SEM of 3-4 independent experiments performed in duplicate. *: $p<0.05$, **: $p<0.0$ I, ***: $p<0.00$ I versus IL-I $\beta$ (I 0 $\mathrm{U} / \mathrm{mL}$ ) alone.

cytokines in the asthmatic airway inflammation, as also suggested from recent studies in humans [35,36] as well as from animal models of asthma [37]. More work is needed to clarify the role and pathogenic importance of Th1/Th2 cytokines and neurotrophin release in asthma pathogenesis.

Proliferation and survival of mast cells, eosinophils and lymphocytes in the airways may be of importance in establishment and maintenance of a chronic inflammation. In asthmatic subjects, NGF, BDNF, NT-3 and NT-4 significantly enhanced airway eosinophil survival [38]. Mast cells located in human asthmatic bronchus have been demonstrated to express the neurotrophin receptor TrkA [11] and NGF may enhance mast cell proliferation and survival [6]. Since mast cells have been shown to be in close contact with smooth muscle cells in the asthmatic bronchus [39], smooth muscle cell-derived NGF has the potential to influence airway mast cells. B and $\mathrm{T}$ lymphocytes, including $\mathrm{CD}^{+} \mathrm{T}$ cells, express the neurotrophin receptors TrkA and TrkB, and NGF has been shown to enhance proliferation of $\mathrm{B}$ and $\mathrm{T}$ cells and survival of B cells [6]. Thus, there is evidence for a broad regulatory role for neurotrophins in the airways. In addition to cells of the immune system, neurones may also be targets for the neurotrophins in the airways. Hence, NGF has been shown to increase the number of neurones and the neuropeptide content in the airways $[15,16]$, and both
NGF and BDNF may evoke airway hyperreactivity in the airways [12-14]. In this respect, it is interesting to note that while both NGF and BDNF have been shown to evoke airway hyperreactivity in animal studies [12-14], they may have distinct roles in allergen-dependent airway obstruction [24]. Hence, NGF may play a role in the early airway response (EAR) in asthma, since anti-NGF attenuated the early allergen-induced bronchoconstriction $[13,40,41]$, and NGF causes histamine release from mast cells [42] and basophils [43]. Anti-NGF-treated mice also reduced the eosinophil recruitment to the airways and decreased IL-4 and IL-5 production [40], and IL-1 $\beta$ induced airway hyperactivity in isolated human bronchus [44]. BDNF, on the other hand, seems not to influence the EAR but rather to abrogate chronic airway obstruction [23]. Thus, NGF and BDNF may influence different phases of the allergic response. Interestingly, there are also indications of a differential in vivo production of the neurotrophins in allergic airway inflammation. Hence, following allergen challenge, NGF levels in bronchoalveolar lavage were increased fourfold at 18-24 h, whereas the increase in BDNF peaked after 1 week [24]. An interesting possibility is that that the differential functional effects and secretion observed between NGF and BDNF in vivo might somehow reflect a differential release patterns, such as the one described in our study. 
In the present study, HBSMC were obtained from a healthy donor. An important next step will be to obtain airway smooth muscle cells from asthmatic donors, and ask whether such cells are similar to HBSMC from normal individuals or in some way biased towards production of a different set of neurotrophins [45]. Also, an important next step will be to test whether inflammatory and asthma-associated mediators might have different effects on asthmatic as compared to non-asthmatic bronchial smooth muscle $[45,46]$.

\section{Conclusion}

In conclusion, this study shows that HBSMC are a source of NGF, BDNF and NT-3 in the airways, that IL- $1 \beta$, IFN- $\gamma$ and IL-4 may alter this production differently, and that the IL-1 $\beta$-dependent BDNF, but not IL-1 $\beta$-dependent NGF, secretion is COX-2-dependent. Taken together, we propose a paracrine interaction between smooth muscle cells, neurones, inflammatory cells and structural cells in the vicinity, in which neurotrophins derived from bronchial smooth muscle may promote airway hyperreactivity, inflammation and tissue remodelling.

\section{Competing interests}

The author(s) declare that they have no competing interests.

\section{Authors' contributions}

CK carried out the majority of the experiments, did the statistical analysis and participated in writing the manuscript. JG participated in the design of the study and writing the manuscript. AE participated in the design of the study. $\mathrm{COH}$ conceived of the study and its design, performed its co-ordination, did parts of the experiments and statistical analysis and participated in writing the manuscript. All authors have read and approved the final manuscript.

\section{Acknowledgements}

The present work was funded by the Swedish Research Council, Swedish Heart and Lung Foundation, Swedish Society of Medicine, Swedish Asthma and Allergy Association, Magnus Bergvall's Foundation, Tore Nilson's Foundation, Torsten and Ragnar Söderberg's Foundations, Åke Wiberg's Foundation, and Karolinska Institutet. We thank Dr P. Hoglund for valuable discussions.

\section{References}

I. Lemanske RFJ, Busse WW: 6. Asthma. J Allergy Clin Immunol 2003, I I I:S502-19.

2. Bai TR, Knight DA: Structural changes in the airways in asthma: observations and consequences. Clin Sci (Lond) 2005, 108:463-477.

3. Joos GF: Bronchial hyperresponsiveness: too complex to be useful? Curr Opin Pharmacol 2003, 3:233-238.

4. Lewin GR, Barde YA: Physiology of the neurotrophins. Annu Rev Neurosci 1996, 19:289-317.

5. Olgart Hoglund C, Frossard N: Nerve growth factor and asthma. Pulm Pharmacol Ther 2002, 15:5I-60.

6. Vega JA, Garcia-Suarez O, Hannestad J, Perez-Perez M, Germana A: Neurotrophins and the immune system. J Anat 2003, 203:I-19.
7. Bonini S, Lambiase A, Angelucci F, Magrini L, Manni L, Aloe L: Circulating nerve growth factor levels are increased in humans with allergic diseases and asthma. Proc Natl Acad Sci U S A 1996, 93:10955-10960

8. Noga O, Hanf G, Schaper C, O'Connor A, Kunkel G: The influence of inhalative corticosteroids on circulating Nerve Growth Factor, Brain-Derived Neurotrophic Factor and Neurotrophin-3 in allergic asthmatics. Clin Exp Allergy 200I, 3I:1906-1912.

9. Virchow JC, Julius P, Lommatzsch M, Luttmann W, Renz H, Braun A: Neurotrophins are increased in bronchoalveolar lavage fluid after segmental allergen provocation. Am J Respir Crit Care Med 1998, I 58:2002-2005.

10. Olgart Hoglund C, de Blay F, Oster JP, Duvernelle C, Kassel O, Pauli G, Frossard N: Nerve growth factor levels and localisation in human asthmatic bronchi. Eur Respir J 2002, 20: I I I0-III6.

II. Kassel O, de Blay F, Duvernelle C, Olgart C, Israel-Biet D, Krieger P, Moreau L, Muller C, Pauli G, Frossard N: Local increase in the number of mast cells and expression of nerve growth factor in the bronchus of asthmatic patients after repeated inhalation of allergen at low-dose. Clin Exp Allergy 200 I, 3 I: I 432 - I 440.

12. Braun A, Appel E, Baruch R, Herz U, Botchkarev V, Paus R, Brodie C, Renz $\mathrm{H}$ : Role of nerve growth factor in a mouse model of allergic airway inflammation and asthma. Eur J Immunol I998, 28:3240-325I.

13. de Vries A, Dessing MC, Engels F, Henricks PA, Nijkamp FP: Nerve growth factor induces a neurokinin-I receptor- mediated airway hyperresponsiveness in guinea pigs. Am J Respir Crit Care Med 1999, I59: | 54I-1544.

14. Braun A, Lommatzsch M, Mannsfeldt A, Neuhaus-Steinmetz U, Fischer A, Schnoy N, Lewin GR, Renz H: Cellular sources of enhanced brain-derived neurotrophic factor production in a mouse model of allergic inflammation. Am J Respir Cell Mol Biol 1999, 2 1:537-546.

15. Hoyle GW, Graham RM, Finkelstein JB, Nguyen KP, Gozal D, Friedman $M$ : Hyperinnervation of the airways in transgenic mice overexpressing nerve growth factor. Am J Respir Cell Mol Biol 1998, 18:149-157.

16. Hunter DD, Myers AC, Undem BJ: Nerve growth factor-induced phenotypic switch in guinea pig airway sensory neurons. Am J Respir Crit Care Med 2000, 16 1:1985-1990.

17. Micera A, Vigneti E, Pickholtz D, Reich R, Pappo O, Bonini S, Maquart FX, Aloe L, Levi-Schaffer F: Nerve growth factor displays stimulatory effects on human skin and lung fibroblasts, demonstrating a direct role for this factor in tissue repair. Proc Natl Acad Sci U S A 200I, 98:6162-6I67.

18. Kohyama T, Liu X, Wen FQ, Kobayashi T, Abe S, Ertl R, Rennard SI: Nerve growth factor stimulates fibronectin-induced fibroblast migration. J Lab Clin Med 2002, 140:329-335.

19. Levine ES, Dreyfus CF, Black IB, Plummer MR: Differential effects of NGF and BDNF on voltage-gated calcium currents in embryonic basal forebrain neurons. I Neurosci 1995, | 5:3084-309|.

20. Oyelese AA, Rizzo MA, Waxman SG, Kocsis JD: Differential effects of NGF and BDNF on axotomy-induced changes in GABA(A)-receptor-mediated conductance and sodium currents in cutaneous afferent neurons. I Neurophysiol 1997, 78:3I-42.

21. Carter BD, Zirrgiebel U, Barde YA: Differential regulation of p2 I ras activation in neurons by nerve growth factor and brain-derived neurotrophic factor. I Biol Chem 1995, 270:2|75|-2|757.

22. Botchkarev VA, Botchkareva NV, Peters EM, Paus R: Epithelial growth control by neurotrophins: leads and lessons from the hair follicle. Prog Brain Res 2004, I 46:493-5I3.

23. Braun A, Lommatzsch M, Neuhaus-Steinmetz U, Quarcoo D, Glaab T, McGregor GP, Fischer A, Renz H: Brain-derived neurotrophic factor (BDNF) contributes to neuronal dysfunction in a model of allergic airway inflammation. Br J Pharmacol 2004, | 41:43 | -440.

24. Lommatzsch $M$, Braun $A$, Renz $H$ : Neurotrophins in allergic airway dysfunction: what the mouse model is teaching us. Ann N Y Acad Sci 2003, 992:24I-249.

25. Kimata H: Brain-derived neurotrophic factor selectively enhances allergen-specific IgE production. Neuropeptides 2005, 39:379-383. 
26. Fox AJ, Patel HJ, Barnes PJ, Belvisi MG: Release of nerve growth factor by human pulmonary epithelial cells: role in airway inflammatory diseases. Eur J Pharmacol 200I, 424: I59-162.

27. Freund V, Pons F, Joly V, Mathieu E, Martinet N, Frossard N: Upregulation of nerve growth factor expression by human airway smooth muscle cells in inflammatory conditions. Eur Respir J 2002, 20:458-463.

28. Ricci A, Felici L, Mariotta S, Mannino F, Schmid G, Terzano C, Cardillo G, Amenta F, Bronzetti E: Neurotrophin and neurotrophin receptor protein expression in the human lung. Am J Respir Cell Mol Biol 2004, 30:12-19.

29. Shaw KN, Commins S, O'Mara SM: Deficits in spatial learning and synaptic plasticity induced by the rapid and competitive broad-spectrum cyclooxygenase inhibitor ibuprofen are reversed by increasing endogenous brain-derived neurotrophic factor. Eur J Neurosci 2003, I 7:2438-2446.

30. Hirst S): Airway smooth muscle cell culture: application to studies of airway wall remodelling and phenotype plasticity in asthma. Eur Respir J 1996, 9:808-820.

31. Pang L, Knox A): Effect of interleukin-I beta, tumour necrosis factor-alpha and interferon-gamma on the induction of cyclo-oxygenase- 2 in cultured human airway smooth muscle cells. Br J Pharmacol 1997, I 2 I:579-587.

32. Barnes PJ, Chung KF, Page CP: Inflammatory mediators of asthma: an update. Pharmacol Rev 1998, 50:515-596.

33. Groneberg DA, Peiser C, Eynott PR, Welker P, Erbes R, Witt C, Chung KF, Fischer A: Transcriptional down-regulation of neurotrophin-3 in chronic obstructive pulmonary disease. Biol Chem 2005, 386:53-59.

34. Toyomoto M, Ohta M, Okumura K, Yano H, Matsumoto K, Inoue S, Hayashi K, lkeda K: Prostaglandins are powerful inducers of NGF and BDNF production in mouse astrocyte cultures. FEBS Lett 2004, 562:2 I I-2I 5.

35. Corrigan CJ, Kay AB: CD4 T-lymphocyte activation in acute severe asthma. Relationship to disease severity and atopic status. Am Rev Respir Dis 1990, 141:970-977.

36. ten Hacken NH, Oosterhoff Y, Kauffman HF, Guevarra L, Satoh T, Tollerud DJ, Postma DS: Elevated serum interferon-gamma in atopic asthma correlates with increased airways responsiveness and circadian peak expiratory flow variation. Eur Respir J |998, I I:3 | 2-3 |6.

37. Dahl ME, Dabbagh K, Liggitt D, Kim S, Lewis DB: Viral-induced T helper type I responses enhance allergic disease by effects on lung dendritic cells. Nat Immunol 2004, 5:337-343.

38. Nassenstein C, Braun A, Erpenbeck VJ, Lommatzsch M, Schmidt S, Krug N, Luttmann W, Renz H, Virchow JCJ: The neurotrophins nerve growth factor, brain-derived neurotrophic factor, neurotrophin-3, and neurotrophin-4 are survival and activation factors for eosinophils in patients with allergic bronchial asthma. J Exp Med 2003, I 98:455-467.

39. Brightling CE, Bradding P, Symon FA, Holgate ST, Wardlaw AJ, Pavord ID: Mast-cell infiltration of airway smooth muscle in asthma. N Engl J Med 2002, 346:1699-I705.

40. Path G, Braun A, Meents N, Kerzel S, Quarcoo D, Raap U, Hoyle GW, Nockher WA, Renz H: Augmentation of allergic earlyphase reaction by nerve growth factor. Am J Respir Crit Care Med 2002, 1 66:818-826.

41. De Vries A, Engels F, Henricks PA, Leusink-Muis T, Fischer A, Nijkamp FP: Antibodies directed against nerve growth factor inhibit the acute bronchoconstriction due to allergen challenge in guinea-pigs. Clin Exp Allergy 2002, 32:325-328.

42. Bruni A, Bigon E, Boarato E, Mietto L, Leon A, Toffano G: Interaction between nerve growth factor and lysophosphatidylserine on rat peritoneal mast cells. FEBS Lett 1982, 138:190-192.

43. Bischoff SC, Dahinden CA: Effect of nerve growth factor on the release of inflammatory mediators by mature human basophils. Blood 1992, 79:2662-2669.

44. Frossard N, Naline E, Olgart Hoglund C, Georges O, Advenier C: Nerve growth factor is released by IL-Ibeta and induces hyperresponsiveness of the human isolated bronchus. Eur Respir J 2005, 26: 15-20.

45. Chambers LS, Black JL, Ge Q, Carlin SM, Au WW, Poniris M, Thompson J, Johnson PR, Burgess JK: PAR-2 activation, PGE2, and COX-2 in human asthmatic and nonasthmatic airway smooth muscle cells. Am J Physiol Lung Cell Mol Physiol 2003, 285:L619-27.
46. Burgess JK, Ge Q, Boustany S, Black JL, Johnson PR: Increased sensitivity of asthmatic airway smooth muscle cells to prostaglandin E2 might be mediated by increased numbers of Eprostanoid receptors. J Allergy Clin Immunol 2004, I I 3:876-88I.
Publish with Biomed Central and every scientist can read your work free of charge

"BioMed Central will be the most significant development for disseminating the results of biomedical research in our lifetime. "

Sir Paul Nurse, Cancer Research UK

Your research papers will be:

- available free of charge to the entire biomedical community

- peer reviewed and published immediately upon acceptance

- cited in PubMed and archived on PubMed Central

- yours - you keep the copyright

Submit your manuscript here:

http://www.biomedcentral.com/info/publishing_adv.asp
BioMedcentral 